\title{
厚生省特定疾患前庭機能異常調査研究のまとめ
}

\section{（付） 両側変動難聴性メニエール病診断基準と}

内リンパ水腫を推定する検査の手引

\author{
北 原 正 章
}

\section{[I] 研 究目標}

前庭機能異常とは内耳と/または第 8 脳神経障害に上 るめまいを主要症状とする疾患群の総称である。上記の らち代表的疾患であるメニエール病はめまい発作の反復 を主徴とし，原因並びに発作の機序にも不明の点が多 く, 最も治療に苦渋する疾患である。メニエール病はま た症例も多く，その一部ではめまい発作の頻発，持続性 平衡失調, 難聴, 耳鳴，両耳羅患などのため高度飞社会 生活が障害されている。

本研究はこのメニエール病に焦点を当て, 過去の研究 成果を踏委光疫学調查, 基礎・臨床研究を進めその成果 を本疾患の診断々予後の向上に資することを目的とし， 得られた知見は更にメニエール病と類似の病態を持つ内 耳炎, 遅発性内リンパ水腫等の診断治療にも応用しょう とするものである。

\section{[II] 研究成果}

1. 疫学 (難病の疫学調查研究班の指導, 協力のもとに 行われた）

第一に全国のメニエール病患者数を把握し，その臨床 疫学像を明確にし，発症要因検討の基礎資料を得るた め，昭和60年 1 月 1 日から同年12月 31 日までを調查期間 として，全国 200 床以上の 4,038 医療機関を対象に第一 次全国調查を昭和61年11月に行った。調查再依頼も含め 最終的に回答率は $37 \%$ となりメニエール病確実例 3,599 , 疑い例 4,673であった。更に詳しい疫学臨床像を把握す るための第二次調査は，第一次調査で患者有りとの報告 のあった 538 機関を対象に行った。両依頼も含めて昭和 63 年 8 月 15 日までに回答率 $46.2 \%$, 複数の医療機関から の同一患者の重複報告をチェック後の患者数は，メ二エ 一儿病確実例 1,564，疑い1,439 であった。

第二に重症メニエール病（仮称）の実態調査を昭和63 滋賀医科大学耳鼻咽喉科学教室
年 4 月 1 日から同年 9 月 31 日まで調查研究班員並び飞研 究協力者所属16施設を対象に行った。調查されたメ二エ 一ル病は確実例 493，疑い例 155 であった。

(1) $x=エ ー ル$ 病有病率, 疫学基本項目, 臨床疫学像 上記資料を基化有病率の推定，年歯分布，患側，受療 状沉, めまい・耳鳴・難聴の経過等の基本項目, 臨床疫 学像について解析された。メニエール病の発生率は 5.8 人/人口 10 万（200 床以上の病院）と推計され，男性 1 に対し女性 1.6 で女性多発傾向は確かになった。

(2) 重症メニエール病（仮称）は䛦断基準の項で述べ る。

(3) メニエール病発症背景因子に関する疫学調查

国立精神衛生研究所作成の環境变化調查表によるアン ケート調查を富山県に打いてィニエール病確実例12例を 対象に行った。調査対象期間中にめまい発作を生じた 7 例の平均ストレス量は発作を生じなかった 5 例のそれよ り高值を示し，ストレスが発作の背景因子として重要な 役割を果たす可能性が推定された。

\section{2. 病因・病態生理}

メニエール病は一般に症候学的立場から規定されてお るが，ィニエール病剖検例の内耳にはライスネル膜の伸 展が見られることから特発性内リンパ水腫だとする考兄 が大勢を占めている。そこで，この分野では何故内リン パ水腫が出来るのか? 内リンパ水腫と発作との関わりは 何か？を追求することとした。なお，メニェール病診断 のための検査，治療に直接関わる基礎的な知見は当該項 で述べる。

(1) メニエール病の局所病因

(1) 実験的内リンパ水腫の発生

内リンパ水腫の発生には内リンパ液の血管条に和訬る 分泌過剩や内リン八゚囊に於ける吸収障害が考えられてい る。血管条に抢忷る内リンパ液の発生は ATPase によ 
るイオンの能動輸送などが考えられるがこれら酵素の内 リンパ囊を含めた内耳での局在や作用がモルモットで検 討された。音響外傷による血管条の血行障害や中耳炎に よってもモルモットで内リンパ水腫の作られることが確 かめられた。モルモットにヒスタミンを投与しても明か な内リンパ水腫は生じない。一力内リンパ囊閉塞モルモ ットは, 内リンパ水腫を生ずるだけでめまい発作を生じ ないが，内リンパ囊閉塞モルモットにヒスタミンを投与 することで, めまい発作を作ることが出来た。従来内リ ンパ水腫のモデルを作ることはできたが，ここで初めて， めまい発作を伴らメニエール病モデルを作成することが 出来た。なおこのモデルでは内耳に炎症像は見られてい ない。

(2) ヒト側頭骨の形態

メニエール病の局所病因に内耳の血管異常や未熟が予想 されるが，後者で $60 \%$ にライスネル膜の伸展がみられ た。この場合, 前庭水管の未発達形態も伴っていた。当 該部の画像診断から内リンパ水腫の発生しやすい耳の予 知の可能性が示唆された。ちなみにメニエール病患耳の 前庭水管は未発達のことが多いとの報告も同時になされ た。

生前にめまいを訴えた症例の側頭骨の検索ではライス ネル膜の伸展，前庭神経核变性，動脈硬化などがみられ た。死後変化の除外は難しい問題だが症候と局所病変の 橋渡しという意味で今後の検討が待たれる。

(2) メニエール病の全身に打ける病因

メニエール病の病因は自律神経異常, 血液凝集能異 常, 免疫異常, 心理的要因との関連下で検討されたが今 後の検討が必要である。

(3) メニエール病の病態生理

メニエール病の発作は内リンパ水腫に関連しどのよう な機構で発生するのか, 内耳圧と外リンパのカリウム濃 度に焦点を当て検討を進めた。更に内耳の部位による特 性から症状の多様性を考光た。

(1) 内耳圧

発作の発生には内耳圧の旮進がまず推定される。正常 モルモットで内外リンパ圧差は殆ど計測できないし，内 外リンパ压を同時に上昇させても（400〜 $500 \mathrm{~mm}$ 水柱） $\mathrm{CM}$ 出力低下は $5 \mathrm{~dB}$ 悪化する程度であった。内リンパ 囊閉塞による内リンパ水腫モルモットでも内外リンパ圧 差は殆ど計測できない程度であった。しかし内リンパ囊 閉塞 1 週間以内の水腫モルモットでは -SP の巨大化が みられ，鼓室階に压負荷（300 $\mathrm{mm}$ 水柱）を行うと正常 モルモットでは内外リンパ圧差のため CM 䦨值覀化を 見るが，このよらな水腫モルモットでは閾值悪化の見ら れないことから内リンパ圧の高いのは内リンパ囊閉塞後
早期であると考えられた。このように内リンパ囊閉塞に よる水腫では初期に内耳圧の上昇することが分かった が, 内耳圧上昇による刺激は前庭器から前庭神経, 前庭 神経核に伝達されることが確認された。

(2) 外リンパ液のカリウム濃度

カリウムは神経毒として作用するから, 水腫が巨大化 すると膜迷路が破裂して生ずる外りンパ液中のカリウム 濃度上昇がメニエール病の発作であるとの考学がある。 実際外リンパ腔にカリウムを付加すると発作と同様な患 側向き自発眼振やメニエール病に見られる蝸電図による -SPの増大が証明された。まためまい発作を生じたモル モット（前述）ではライルネル膜の破裂が実際に見られ た。

(3) メニエール病の症状の多様性について

内リンパ腔は連続した単一の腔であるが, 各部で電位 や電解質, 蛋白の含有量に相違のあることが知られてい る。部位による相違は膜迷路の力学特性, 水腫発生時の 膜伸展度, 伸展速度, ADP による酸素分圧低下度など にも見られた。これらの事実はメニエール病の経過や症 候の多様性と関連を持つものと思われる。

3. 臨休研究

(1) 診断

メニエール病の診断に関しては内リンパ水腫を推定す るグリセロール試験, フロセミド試験, 蝸電図検査の検 查法, 診断意義について検討された。予後の悪い両側 ニエール病に関する謋断基準も作成された。これらにつ いては [IV] 1 に述べる。また外耳道に圧を与えて生ず る前庭反射から診断を行拈らとする試みも進行中である が一定の結論を得るには更に検討を続ける必要がある。

(2) 予後

長期観察によるとメニエール病の 聴力はまず悪化す る。健側耳の悪化も $40 \%$ に見られる。めはい発作も 50 \%に存続する。予後の推定には患側迷路向きの眼振力向 優位生，起立性調節障害等の背景因子の消長が鍵を握る といら見解もあったが，数年に及ぶ休止期を経て悪化す る例, 改善する例などがあり, 現段階で予後の判定は難 しいと考える。

(3) 治療

病因に対する治療に関して新しい展開は得られなかっ たが，主に内リンパ水腫に対する治療の前進は注目され ている。

(1) 血管拡張剂

メニエール病の治療には血管拡張剤が頻用されているが 各種薬剂の内耳血流に及ぼす影響がレーザードップラー 法で検討され始めている。血圧を上げずに内耳血流を増 加する薬物の選択が期待される。 
(2) ステロイド

ステロイドはその抗炎症作用，免疫抑制作用を期待し てメニエール病に使用される。ステロイドは症状悪化の 初期に有効だが長期連用では効果が乏しくなるから初期 に十分な量の投与が必要である。基礎実験でも内リンパ 水腫モルモットには初期投与が有効であり，正常モルモ ットで内耳血管の透過性を減ずることも分かった。

(3) イソソルバイド

イソソルバイドは高浸透压利尿剤であるが本調査研究 班員が中心となり，メニエール病に対する適応桩大を得 た。従来の薬剤に比し, 発作防止効果, 持続性めまいに 対する効果が優れている。この効果は特にグリセロール 試験陽性例に著明であった。更に投与法について子検討 されている。基礎実験で本剂がモルモットの内リンパ水 腫を軽減することも確認された。ちなみにイソソルバイ ドは海外においても試用され始めている。

(4) TTS スコポラミン

空酔い予防に開発された TTS スコポラミンは間歇期 の連用では效果を見ないが発作の予防に有効である事が 分かった。

(5)内リンパ囊外壁翻転手術

内リンパ水腫に対して水腫軽減のための内リンパ囊 に乳様部に向けて孔を開け，しかも孔の閉鎖を防ぐ手 術であるが，班員の施設を中心に全国 8 施設 314 手術例 $1 \sim 2$ 年以上の成績が纆められた。めまい発作に対して 91\%以上に有効であり, 聴力は 42１5\%の症例に改善を 久た。手術をグリセロール試験陽性例に限ると有効率は 飛躍的に上昇した。

(6) リハビリテーション

メニエール病の平衡障害に対するリハビリテーション の効果が重心動摇計や長大床反力計で吟味され継続治療 の必要性が強調された。

(4) メニエール病以外の内リンパ水腫の診断と治療

中耳炎に併存する軽度の内耳炎, 突癹性難聴, 遅発性 内リンパ水腫の一部にグリセロール試験, フロセミド試 験, 螖電図検査などにより水腫を推定できた。またこれ らの症例の臨床像が明らかにされると共に, メニエール 病に準ずる治療を行うこでより良好な予後が得られるよ らになった。

\section{[III] 国外の研究状況の概要}

この 3 年間, メニエール病は 86 年度第 2 回国際内耳外 科学会並びにメニエール協会総会 (アスペン), 87年国際 平衡神経学会 (ボロニア), 88 年第 2 回国際メニエール病 シンポジウム (ボストン) と頻繁に取り上げられ, 海外 でも注目すべき疾患であるとの認識が益々高まってい る。これらの国際学会には本調查研究班関係者も多数参 画しているが，88年10月には京都で 5 名の海外の有力从
ニエール病研究者を招聘して本調査研究班との合同会議 を行い, 実りの多い活発な討議がなされた。海外の研究 者からこの種の会議は今後も持らたいとの要望があっ た。海外でメニエール病の共同調查研究は持こなわれて いない。保存治療はわが国のそれと大差無いが，前述の よらにイソソルバイドは本調查研究班員を中心にメニエ 一ル病に対する有效性が確かめられ，その使用は海外に も普及しつつ㐫る。手術症例数はわが国と比較し桁違い に多かったが, 最近ではわが国の症例数もきわめて増加 しこの分野でも世界の最前線を進むようになった。

\section{[IV ]メニエール病の診断基準, 基礎的知見など}

\section{1. 診断基準}

(1) 内リンパ水腫を推定する検査の手引

先の渡辺勈班長により作成されたメニエール病の診断 基準ではその後精細な平衡機能検査, 画像診断などを導 入乙て除外診断法の向上を図ってきたが，メニエール病 の病態が内リンパ水腫であることが確実視されているこ とから当班の目標は内リンパ水腫を推定する検查法の確 立に向けられてきた。グリセロール試験, フロセミド試 験, 蝸電四検査（表 1) がそれである。この 3 検査につ いて検査法, 判定, 成績の意義に関する手引が作成され た。先のメニエール病の診断基準は自覚症状と除外規定 からのみ成立しているが，メニエール病の診断はより積 極的確実に打こなえる様になり, 薬物の選択や手術適応 決定にも有效であることが分かってきた。メニエール病 以外の疾患の水腫も推定できる様になった。これらの検 查に関わる基礎実験は [IV] 2 に述べる。

(2) 両側変動難聴性メニエール病診断基準

メニエール病の中で特に予後の悪い疾患として両側 メニエール病が注目されてきた。然しとの診断基準が無 いために雨側メニエール病の研究は国際的にみても個々 の研究に終始している。そこで共同調查研究を行い易い ように両側変動難聴性メ二エール病確実例並びに疑い例 の謋断基準（表 2）を作成した。

昭和63年10月班員並びに研究協力者の所属する臨床施 設で行った 480 メニール病確実例の調查によると両側 変動難聴性メニエール病は一側メニエール病と比較し高 齢発症者に多く, 罹病期間は長期で（一側メニエール病 6.5 年, 兩側変動難聴性メニエール病 9.9年), 全体の経過 からみても改善傾向は少なく, めまい群発型から持続型 への移行, 聴力は両耳の高度難聴が見られ, 両側変動難 聴性メニエール病の中 $42 \%$ は主治医から重症だと考えら れていたが，一側メニエール病で重症と考えられていた 症例は $5 \%$ に過ぎなかった。な敃調査対象となった全メ ニエール病確実例の中, 両側変動難聴性メニエール病の 占める割合は $28.8 \%$ で，これを罹病期間 20 年以上症例の 


\section{グリセロール試験}

方法 : 被検者には予め絶食させる。純音聴力測定後直ちに $1.3 \mathrm{~g} / \mathrm{kg}$ のグリセロールに同量の生食水を 加光服用させる。 $50 \%$ グリセロール含有液（アミラック）使用の時は $2.6 \mathrm{~g} / \mathrm{kg}$ となる。3 時間 安静 (横臥) の後, 再度純音聴力検査を行う。検者は同一であることが望ましい。

判定 : 閾值が後検查で, 2 つ上の周波数について $10 \mathrm{~dB}$ 以上の改善を見たときは, 本検查陽性とす る。3 周波数 $(200,500,1000 \mathrm{~Hz})$ で平均 $5.0 \mathrm{~dB}, 1$ 周波数について $10 \mathrm{~dB}$ 以上の改善を示 したときは，疑陽性とする。

禁忌 : 急性硬膜下・外出血の予想される患者, 高度の糖尿病患者, 血圧変動の激しい患者, 腎不全患者 など。

意義 : 本検查陽性は変動する難聴を示すもので，メニエール病診断基準第 2 項 “耳鳴難聴などの蝸牛症 状が反復消長すること” (厚生省特定疾患メニエール病調査研究班昭和49年度研究報告書, p. 5) の曖昧な場合，これを補完する。本検查はメニエール病，梅毒性内耳炎の水腫の存在が考えられ ている疾患群の 45 55\% に陽性を示すが，水腫の存在が考兄られない疾患群では陽性を示さな い。従って本検査が陽性であることは, 強く内リンパ水腫の存在を示唆する。しかし聴神経腫崲 で陽性を示したといら報告がある。

備考：グリセロール静注等の変法があるが成績はほぼ同様である。

\section{フロセミド試験}

方法 : 平均 $750 \mathrm{~m} l$ の利尿があるので絶食は必要ない。30 ${ }^{\circ} \mathrm{C}$ (または $44^{\circ} \mathrm{C}$ ) $50 \mathrm{~m} l, 20$ 秒の温度刺激を 两耳について行い, 温度眼振の最大緩除相速度を測定する。ついでフロセミド $20 \mathrm{mg}, 2 \mathrm{ml}$ を静 注， 1 時間後に同様の検查を行う。

判定：1時間後の眼振緩除相速度が静注前のそれの10\%以上增加する場合，本検查陽性とする。

禁忌：アミノ配糖体剂使用中の患者。その他はグリセロール試験のそれそ準ずる。

意義 : 本検査はメニエール病, 遅発性内リンパ水腫, 梅毒性内耳炎の水腫の存在が考兄らている疾患 群の50 90\%に陽性を示し, 内リンパ水腫を示唆するが, 水腫の存在が考兄られない疾患群につ いても $6 \%$ 以下であるが，陽性例がある。

備考：フロセミド投与前後の反応を振子様回転検查，台形方式回転検査やVOR 検查で見る変法がある が，この場合の成績も注ぼ同様である。

\section{蝸電図検查}

方法：クリック音刺激（例えば $80 \mathrm{~dB}$ pe SPL）を用い鼓室外誘導蝸電図検査を行い, - $\mathrm{SP} / \mathrm{AP}$ を求め る。

判定：- $\mathrm{SP} / \mathrm{AP}$ が 0.36〜0.50 以上を陽性とする。方法によりこの值は多少異なる。

意義: 本検査はメニエール病, 梅毒性内耳炎の水腫の存在の考光られている疾患群の約 $60 \%$ に陽性を示 し内リンパ水腫を示唆するが, 水腫の存在が考兄られていない疾患群についても 4 〜 $10 \%$ 陽性を 示す。

備考：トーンバースト刺激, 鼓室内誘導との比較検討は残された課題である。

に限ると $41.5 \%$ にも及゙事が分かった。この調査を更に 拡大していくことでいわゆる雨側メニエール病の本質を 解明したいと考えている。

(3) 重症メニエール病（仮称）

冒頭で述ベたように，一部のメニェール病患者は高度 に社会生活が障害されるまで疾患は進行する。これらの 一群はわれわれの調查研究の中核をなし高度の治療を必 要とするとの認識から, 重症メニエール病の実態調査を
前項の調查と同時に行った。調査症例はメニエール病確 実と疑い例 657でうち $21.8 \%$ が主治医により重症と判断 された。判断の根拠には両側性, 長期罹患, 平衡障害が 多く，これらと共に進行性，社会的問題などもしばしば 取り上げられた。重症メニエール病は男性に多く（男性 $25.9 \%$,女性 18.8\%), 年齢は40～60歳台に集中し，重症 例は罹病期間別にみると 5 年以上の症例に多く，両側中 等度以上の感音難聴, 温度眼振検査異常所見が多数にみ 


\section{表 2 両側変動難聴性メニエール病 (Meniere's disease with bilateral fluctuant hearing loss) 診断基準}

1、回転性めまいを反復すること。

(1) めまいは一般に特別の誘因なく発来し，嘔気，嘔吐をともない，数分ないし数時間持続する。

(2) 発作の中には回転性めまいでない場合もある。

(3) 反復性の確認され妨初回発作では，めまいを伴ら突発性難聴と十分鑑別されなければならない。

\section{2. 両耳において耳鳴難聴などの蝸牛症状が反復消長すること。}

(1) 耳鳴難聴の両方またはいずれかの変動にともないめまいの発作を来すことが多い。

(2) 耳閉塞感や強い音に対する過敏性を訴える例も多い。

（3）蝸牛症状は両耳同時にまたは交互に現れる。患者は両耳の螖牛症状の消長に気つかか婸合も多 いから，グリセロール試験や頻回の聴力検查が望ましい。

（4）聴力検査では，著明な中，低音部閾値変動や音の大きさの補充現象陽性を呈することが多い。

3 ．1，2の症状を来す中枢疾患，並びに原因既知のめまい，難聴を主訴とする疾患が除外できる。

これらの疾患を除外するためには, 問診, 一般神経学的検查, 平衡機能検查, 聴力検査などを含む 専門的な臨床検査を行い，時には経過観察が必要な場合もある。

\section{診断基準}

1. 確実例：1，2，3の全体条件を多たするの。

2. 疑い例 : 以下の症例でその症候を来す中枢並びそ原因既知のめまい難聴を主訴とする疾患が除外で きるとき。

(1) メニエール病で, 他側耳に耳鳴または難聴を認めるもの。

(2) 回転性めまいを反復し，両耳に耳鳴と／または難聴を認めるもの。

(3) 两耳に於いて耳鳴難㯖等の蝸牛症状を認め, これが少なくとも一側耳に打いて反復消長するも の。

（注）原疾患として，充分に中耳炎，薬物中毒，梅毒など原因既知の疾患を除外し得なかった時は，こ れらの疾患名を併記することとする。

られた。これらの成果を踏まえ重症メニエール病の条件 （試案）が提示された。試案の再吟味も含め, 該当症例の 実数把握，各関連要因の相関，重症化の原因も鋭意検討 中である。

\section{2. 基礎的知見など}

ここでは上記内リンパ水腫を推定する検査法に関する 基礎的知見だけを述べる。

(1) グリセロール試験

内リンパ囊閉塞による内リンパ水腫モルモットではグ リセロール投与で聴覚閾值の改善を見た。組織学的にも ライスネル膜の㱀譬形成を通して内リンパ水腫の減退を 確認出来た。グリセロールが聴覚閾值を改善するのは水 腫の減退によると考えられるが，グリセロールが正常モ ルモットの内耳血流を促進する事実から内耳代謝促進に よるかもしれないといら見解もあった。人では内リンパ 減荷術後本試験成績は陰性化する。

(2) フロセミド試験

内リンパ囊閉塞による内リンパ水腫モルモットでフロ セミド投与後回転刺激に対する反応充進を見た。組織学
的にもグリセロールと同様水腫の減退を見た。人では内 リンパ減荷術後本試験成績は陰性化する。

\section{(3) 螖電困検査}

内リンパ囊閉塞による内リンパ水腫モルモットでは 一般に大きな -SP は見られないが，閉塞直後には巨大 -SPが見られた。外リンパ腔をカリウムで灌流すると同 様に巨大一SPをみた。内耳神経圧迫によっても一SP の 巨大化を来たした。メニェール病での巨大 -SP の成因 はまだ明かでない。

\section{[V] 今後の研究方向及び研究の進め方}

当班の最重点課題としては重症メニエール病調査や, 新しく作成された両側変動難聴性メニエール病の診断基 準にもとづき高度の治療を要する重症あるいは両側メ二 エール病の実態を拏急に解明すると共にそれらの予知診 断, 予防・治療, 更には高歯化に伴ら病像の変化や高度 前庭機能障害に対するリハビリテーションをも取り上げ て行きたいと思う。

疫学では, 厚生省難病の疫学調査研究班の指導を得て メニエール病 3,003 例の臨床疫学像の解析続行, 重症メ 
ニエール病調査とのドッキングなどによるメニエール病 重症化要因の検討, 基礎研究では引き続き内リンパ水腫 の発生・発作機構の解明と水腫の検查治療の基礎固め, 臨床研究では内リンパ水腫を推定する検査手引の吟味, 前庭機能検査による診断法の向上を計る。治療について は新治療開発にむけての探索の活か既知の治療について は病期による治療指針を確立する。

現在でも, ニニール病調查研究で得られた知見は内
耳炎や遅発性内リンパ水腫の診断治療に応用し始めてい るが，この分野の知見を通し残された未知の前庭機能異 常の解明と治療法の開発を進めることも必要である。

$\left(\begin{array}{l}\text { 原稿到着 : 平成 } 1 \text { 年 } 2 \text { 月 } 6 \text { 日 } \\ \text { 別刷請求先 : 北原正章 } \\ \text { 干 } 520-21 \text { 大津市瀬田月輪町 } \\ \text { 滋賀医科大学耳鼻咽喉科学教空 }\end{array}\right)$ 